\title{
Web-Based Resources in EFL Learning: An Enhancement of Students' Digital Literacy
}

\author{
Yunani Atmanegara (corresponding author) \\ Sriwijaya University \\ E-mail: yunani_atmanegara@yahoo.com
}

Sherly Agustina

Sriwijaya University

Desi Tiara

Sriwijaya University

\author{
Doi:10.7575/aiac.alls.v.4n.2p.117 \\ URL: http://dx.doi.org/10.7575/aiac.alls.v.4n.2p.117
}

Received: 03/04/2013

Accepted: 02/06/2013

\begin{abstract}
The shift of information form that is more technological oriented has encouraged EFL teachers to develop their students' literacy skill. This study used web based resources in order to motivate EFL learning and develop students' digital literacy. In conducting this study, twenty students were involved. The data were collected by means of questionnaires consisting of five aspects; students' self-efficacy, learning challenge, learning curiosity, learning involvement and recognition for digital learning. The results of the study show that students are motivated by the use of web-based resources in EFL learning with more appropriate and authentic materials. However, some considerations are needed to be taken into account in selecting the suitable web-based resources. Using web based resources can be an alternative to help the students be motivated in developing their digital literacy learning.
\end{abstract}

Keywords: Web Based Resources, Digital Literacy, Digital Learning, EFL, ICT

\section{Introduction}

The impact of technological advances in this digitalization era has caused people become technologically oriented in accessing the information needed. They can make a use of technology to get the information about current issues easily and efficiently. This change of information form has to be considered both by teachers and students as an opportunity to increase their teaching and learning quality because they can use various technologies as media to support their teaching and learning process. In line with UNESCO (2009), technology can enhance the quality of education with advanced teaching methods, improve learning outcomes and enable reform or better management of education systems. Furthermore, Eristi et.al.(2012) suggest that when technology is effectively used and successfully integrated in educational environments, the productivity of instructional processes can be increased. In other words, technology has some important roles in educational field.

Nowadays, the use of technology as the way to get information related to the study and also as the effective communication tools used in teaching and learning process is well-known with the term of ICT (Information and Communication Technology). The implementation of ICT in this process is to overcome the problems in the area of education. One of its problems is the use of printed materials performed conventionally by the teachers. While in EFL learning, the teachers are supposed to be creative to adapt the materials by using sophisticated media to achieve their learning objectives. Sarahceni in Tomlinson (2003) states that adaptation process is used to make materials relevant and effective for learning development. This material adaptation should be based on authentic texts and realistic situations in order to expose the learners to realistic input. Therefore, Rajaram (2011) suggests that to make English learning become more enjoyable and encouraging, teachers of English should grab the web-based resources and develop creative computer-assisted learning tools.

In this era, the availability of web based resources can be easily found via internet due to digital technology development. In order to create successful EFL learning, both teachers and students have to be familiar with digital sources. As Giffard (2011) states that reading on a digital screen with the use of computer as a medium to read is easier and more user-friendly because most web based resources contain of colors, pictures, sounds, animations and video which are more interactive and fun than printed sources. Besides, these features can also motivate students' independent learning because they can learn by 
themselves once they have known how to use it. There will be more beneficial influences if the teachers can facilitate their students to know about some useful web based resources to be explored.

Therefore, this present study focuses on introducing some web based resources in EFL learning in order to find out whether or not they can motivate learners' digital literacy development in this digitations era.

\section{Using ICT in ELT}

Indonesian government has put ICT to be integrated into curriculum in education. Juridical foundation of education in Indonesia, law number 14/2005 on teacher and lecturer mention that "Every teacher should be able to take advantage of information and communication technology for the purpose of education". In addition, UNESCO (2004) reports that teachers' experience can be enriched by increasing their professional development on ICT.

ICT has some roles in learning process especially in language learning. It becomes a tool and medium that can facilitate people in learning a language. It is also inevitable known that ICT and language learning are two aspects which support each other like two sides of the coin inseparable (Hartoyo, 2010). The effectiveness and efficiency of language learning towards the use of ICT can improve the quality of understanding and mastery of the language studied. However, the effectiveness of this learning tool totally depends on the users. It demands more specific skills both from the teachers and students. Insufficient technical supports at schools and little access to Internet and ICT can prevent them to use ICT in the classroom (Salehi\&Salehi, 2012). Therefore, these barriers should be considered before developing supporting materials by the use of ICT.

\section{Learning EFL through Web Based Resources}

Searching and accessing learning materials, either by the learners themselves or by having instruction from the teachers, provide experiences that can improve EFL learners' knowledge and skill. With the use of web based resources, teachers of English can create some innovative methodologies to make teaching and learning process more informative, interactive, and interesting. Therefore, the use of web based resources in EFL learning should be taken into account in this digitized learning era since they provide a lot of fun games and communicative activities that can reduce the learning stress and anxieties. So that students can relieve the discomfort of learning and arouse their interest and involvement into deep learning and understanding (Rajanam, 2012).

Furthermore, Dogoriti (2010) found out that the majority (91,3\%) of the teachers show positive attitude towards webbased learning like using computers for teaching purposes as long as it is easily accessible and adjusted to their actual needs in primary foreign language education. However, the importance of selecting good web sites and always supporting students throughout the process needs to be emphasized since its disadvantages cannot be ignored. McPherson (2005) states that some students may be confused while navigating the links. This is because some students, especially those who have poor language abilities, may not be able to read independently using web-based resources. Thus, it is important to have teachers' guidance although students are encouraged to read independently using web-based resources.

\section{The Role of Web-Based Resources on Digital Literacy}

New concept of digital literacy is as the reflection of user ability in digitized learning era, which develops along with the development of technology. Martin (2008, p. 167) defines:

"digital literacy is the awareness, attitude and ability of individuals to appropriately use digital tools and facilities to identify, access, manage, integrate, evaluate, analyze and synthesize digital resources, construct new knowledge, create media expressions, and communicate with others, in the context of specific life situations, in order to enable constructive social action, and to reflect upon this process."

Moreover, Eshet-Alkalai\&Soffer $(2012$, p.1) also define "digital literacy as the skills which include the ability to operate computers and navigate the net effectively, to cope with large volumes of information, to evaluate the reliability of information, and to critically assess what seem to be natural (and not ideologically biased) technological tools." This skill needs to be learnt in order to help people collaborate and solve problems effectively in virtual (non face-to-face) learning environments, and to communicate effectively in technology-mediated social participation environments.

Therefore, web-based resources can be used as an alternative media to enhance digital literacy skill. It is supported by the result of a case study from Jun\&Pow (2011) which found out that web-based learning was useful in involving students in digital literacy practices. Moreover, they added that the use of web-based resources could be guided by the teachers in the whole process in order to make the students keep following the teachers' instructions.

\section{Methodology}

This study utilized a blended-learning design, in which for the first and the last meeting were conducted through face-toface interaction with a teacher (one of the researchers) in a classroom. Meanwhile, facebook group application was used as a medium for the teacher to give instruction and provide the link of appropriate web based resources in their virtual learning for six meetings. During the study, the teacher herself selected the materials to be given to the students concerning to the level of the difficulty.

For the participant of this study, it involved 10 female students who were in the eighth grade of Junior High School. They came from three different schools but studied in the same class and at same level in a course outside the school. Purposive sampling was done in selecting those participants since this study used blended-learning style. Before the study was 
conducted, the teacher had very short interview with each participant. The purpose of this interview is just want to make sure that all the participants have supporting learning tools i.e. personal computer or laptop with internet connection at home and also asking about their ability in operating the computer and internet. From the result of the interview, it is found out that all participants of this study have been familiar with the use of computer and internet in their daily lives.

\section{Materials}

The study was carried out for four weeks and eight lessons were administered to the participants. Topics and titles of each lesson were carefully planned based on level of difficulty. The selection of the topics was fit to the materials in the syllabus. Even though in various forms of materials such as picture books, poetry, anecdote, videos and also teenagers short stories, all of those web-based resources providing text for each materials which were chosen by the teachers in terms of the length of the text and the difficulty of the language. The topics are presented in Table 1:

Table 1. Topics and Titles of Lessons

\begin{tabular}{|c|c|c|}
\hline Lesson & Topics / Titles of the Lesson & Resources \\
\hline Lesson 1 & It's about time & http://www.readinga-z.com/ \\
\hline Lesson 2 & Friends around the World & http://www.readinga-z.com/ \\
\hline Lesson 3 & Seven Wonders You can Visit & http://www.readinga-z.com/ \\
\hline Lesson 4 & Jokes about Fathers & http://www.myenglishpages.com/ \\
\hline Lesson 5 & Expressing Myself (Poetry) & http://www.readinga-z.com/ \\
\hline Lesson 6 & Six Health Tips & http://www.myenglishpages.com/ \\
\hline Lesson 7 & Bitter Sweet Chocolate Love & http://storystar.com/ \\
\hline Lesson 8 & Intelligence (video) & http://www.englishcoursevideo.com/ \\
\hline
\end{tabular}

\section{Procedure for Data Collection and Analysis}

A questionnaire was administered to the participants in order to investigate whether or not students were motivated to develop their EFL digital literacy learning by the use of web-based resources. In relation to this, an available questionnaire made by Wigfield\& Guthrie (1997) regarding to motivation in learning was modified refer to the purpose of this study. Therefore, the researcher took five suggested domain measures of motivation including self efficacy, learning challenges, curiosity, involvement and recognition to digital learning. The questionnaire consists of 30 items with a four-point scale of agreement. Then, the data collected from the participants through the questionnaire were tabulated and analyzed through mean.

In addition, Pearson correlation was also used in analyzing the data in order to see the correlation between each aspects and digital literacy.

\section{Result}

The questionnaire consisted of five parts and the responses have been analyzed accordingly. The items have also been arranged based on the highest mean to the lowest one in order to see the result more clearly.

\section{Part 1: Self Efficacy}

Self-efficacy refers to students' belief in whether they have the confidence to learning English through web based resources or not. It can be seen in table 2 .

Table 2. Self Efficacy

\begin{tabular}{|c|l|c|}
\hline No & \multicolumn{1}{|c|}{ Statement } & MEAN \\
\hline 1 & I like being the best at learning English through this WBR & 3.8 \\
\hline 2 & $\begin{array}{l}\text { I like WBR because the text and questions make me } \\
\text { think. }\end{array}$ & 3.7 \\
\hline 3 & \begin{tabular}{l} 
I learn through WBR to improve my English mastery \\
\hline
\end{tabular} & $\mathbf{3 . 7 3}$ \\
\hline
\end{tabular}




\section{Part 2: Learning Challenge}

The items of this part are aimed to find out whether the use of web based resources is challenging or not in EFL learning. The result shows positive side from the use of web based resources when it offers interesting topic in the lesson.

Table 3. Learning Challenge

\begin{tabular}{|c|l|c|}
\hline No & \multicolumn{1}{|c|}{ Statement } & MEAN \\
\hline 4 & $\begin{array}{l}\text { I know that I will learn English better after I have read } \\
\text { these WBR }\end{array}$ & 4 \\
\hline 5 & $\begin{array}{l}\text { I enjoy WBR because I can get involved in learning } \\
\text { English }\end{array}$ & 3.7 \\
\hline 6 & $\begin{array}{l}\text { If WBR discusses something interesting I might read more } \\
\text { about it. }\end{array}$ & 3.5 \\
\hline 7 & $\begin{array}{l}\text { If the WBR is interesting, I don't care how hard it is, I will } \\
\text { still read it }\end{array}$ & 3.4 \\
\hline 8 & $\begin{array}{l}\text { I like challenging WBR } \\
\text { TOTAL }\end{array}$ \\
\hline
\end{tabular}

\section{Part 3: Learning Curiosity}

In order to investigate learners' curiosity about web based resources, these items were administered to the participants. It also aimed to figure out which kind of materials that interest the learners' curiosity in learning the language. The result shows that materials which giving new information and also do not have too many unfamiliar words can attract learners' curiosity in learning a language.

Table 4. Learning Curiosity

\begin{tabular}{|c|l|c|}
\hline No & \multicolumn{1}{|c|}{ Statement } & MEAN \\
\hline 9 & I like to read about new things. & 3.9 \\
\hline 10 & I have favorite topic from this WBR & 3.4 \\
\hline 11 & $\begin{array}{l}\text { I enjoy WBR that discuss about people in different } \\
\text { countries. }\end{array}$ & 3.4 \\
\hline 12 & I don't like WBR when I find the words are too difficult. & 3.2 \\
\hline 13 & I make pictures in my mind when I read WBR & 3 \\
\hline 14 & I try to find right answer for every lesson & 2.8 \\
\hline 15 & I browse other WBR besides teachers recommendations & 2.3 \\
\hline \multicolumn{2}{|c}{ TOTAL } & $\mathbf{3 . 1 4}$ \\
\hline
\end{tabular}

\section{Part 4: Learning Involvement}

It is very important for the teachers to know what makes their students' get involved in learning so that teachers can find appropriate strategy and good materials to be given to the students to support their students' success in learning.

Table 5. Learning Involvement

\begin{tabular}{|c|l|c|}
\hline No & \multicolumn{1}{|c|}{ Statement } & MEAN \\
\hline 16 & I learn new information about topics that interest me from WBR & 3.7 \\
\hline 17 & I usually learn difficult things from this WBR & 3.6 \\
\hline 18 & It is very important to me to be a good English learner in this study & 3.6 \\
\hline 19 & I become a good English learner through this WBR & 3.6 \\
\hline 20 & If the WBR is interesting, I can read difficult material. & 3.6 \\
\hline 21 & I often feel that I have done good job in English learning from this WBR & 3.2 \\
\hline \multicolumn{2}{|r}{ TOTAL } & $\mathbf{3 . 5 5}$ \\
\hline
\end{tabular}




\section{Part 5: Recognition for Digital Learning}

The need to develop digital literacy has to be considered by every learner. Therefore, teachers should involve digital sources in order to help them to have recognition for their digital learning.

Table 6. Recognition for Digital Learning

\begin{tabular}{|c|l|c|}
\hline No & \multicolumn{1}{|c|}{ Statement } & MEAN \\
\hline 22 & $\begin{array}{l}\mid \\
\text { I am willing to work hard to learn English better through this WBR than my } \\
\text { friends. }\end{array}$ & 3.9 \\
\hline 23 & I always do my reading work exactly as the teacher wants it. & 3.6 \\
\hline 24 & I talk to my friends about what I am learning. & 3.5 \\
\hline 25 & Finishing every assignment is very important to me. & 3.5 \\
\hline 26 & I always try to finish my reading on time & 3.5 \\
\hline 27 & I am happy when someone recognizes my English learning through this WBR & 3.3 \\
\hline 28 & I learn a lot of things about English from this WBR & 3.1 \\
\hline 29 & I like to get compliments for my English learning activities & 2.9 \\
\hline 30 & I like having the teacher say I've learnt English well from this digital learning & 2.8 \\
\hline
\end{tabular}

\subsection{Correlation between Each Aspects and Digital Literacy}

Statistical analysis used in this study was Pearson product moment. It is used in order to see the correlation coefficient between each aspects of digital learning and students' digital literacy.

Table 7. Correlation between Each Aspects and Digital Literacy Total

\begin{tabular}{|c|c|c|c|}
\hline $\begin{array}{l}\text { Dependent } \\
\text { Variable }\end{array}$ & $\begin{array}{c}\text { Independent } \\
\text { Variable }\end{array}$ & $\begin{array}{c}\text { Pearson } \\
\text { Correlation }\end{array}$ & $\mathbf{P}<$ \\
\hline \multirow{5}{*}{$\begin{array}{l}\text { Digital } \\
\text { Literacy }\end{array}$} & Self Efficacy & .536 & .015 \\
\hline & Learning Challenge & .699 & .001 \\
\hline & Learning Curiosity & .522 & .018 \\
\hline & $\begin{array}{c}\text { Learning } \\
\text { Involvement }\end{array}$ & .764 & .000 \\
\hline & $\begin{array}{l}\text { Recognition for } \\
\text { Digital Learning }\end{array}$ & .813 & .000 \\
\hline
\end{tabular}

\section{Discussion}

\section{Part 1: Self Efficacy}

Web based resources can build the students confidence in learning a language because students will show their best learning performance if they find out that the materials given by the teachers can create their deeper understanding about the subject matter. As Rajanam (2012) points out that Web is an invaluable treasure of information for teachers to create classroom materials and to explore the whole world just by clicking the mouse. By having more various and authentic learning materials, students can improve their English mastery. In short, web based resources is successful to build students self-efficacy in this study.

\section{Part 2: Learning Challenge}

The result of the questionnaire for part 2 regarding with the use of web based resources to challenge to students' learning is quite satisfying. It means that the students agree web based resources are challenging materials for them but they will learn more about it if they find the topics interest their learning needs. This is similar to a study which was conducted by Kung and Chuo (2002) regarding students' attitudes towards learning English through websites. They found that students showed positive attitudes towards the use of teacher-selected websites in their English learning. Moreover, since it also involved 
blended learning in which for virtual learning style gave the chance to the students to build their learning autonomy. It can enrich their learning experience to become more independent learners.

\section{Part 3: Learning Curiosity}

The total number of this part shows that all the selected materials given to participants through blended learning slightly encourage the students' curiosity. It is also supported from the data of the lowest mean got from item that only few students browse other web based resources besides teacher's recommendations. In other words, students still need teachers' encouragement to hook their curiosity in learning. Even though this part still contributes to students' digital literacy enhancement, the contribution does not give significant result. Meanwhile, a study conducted by Lombardy (2007) found out that web-based resources classified into an open learning initiative. The different result of these two studies can be caused by their different method of teaching. This present study uses blended learning in which the students just had one meeting before having virtual learning. Even though they like to open the links given by the teachers, only few of them open other sources beside teachers' recommendation because they did their virtual learning just to complete their task.

\section{Part 4: Learning Involvement}

From this part, it can be found that using web based resources in EFL learning is effective to get the students involved with teaching materials given. It is important to be engaged in learning in order to create deeper understanding about the subject matter. Positive attitudes from the students show that they will still learn difficult things when they found the topics are worth to be learnt. Vaughan (2010) adds that the use of web-based technology or web-based resources can make the students able to learn better since they can improve their creativity, share the information from the material given by the teacher, and discusses it with their peer.

\section{Part 5: Recognition for Digital Learning}

The use of web based resources can motivate the students to recognize their digital learning development. The students have willingness to develop their English better learning by the use of web based resources. They were quite responsible with all the learning tasks. Moreover, they discuss the topics with others outside the learning process. Vaughan (2010), he found that the potential of using Web 2.0 technologies and educational design strategies can be a key to change the course from traditional to digital one actively or collaboratively in order to make the students responsible for their learning and to match their understanding through discourse and discuss with their peers. From these satisfying findings, it is strongly recommended to involve web based resources in EFL learning to create the students' digital literacy learning enhancement.

\subsection{Correlation between Each Aspects and Digital Literacy}

From the result of statistical analysis using Pearson product moment correlation, it can be seen that each aspects has significant correlation to digital literacy. If we see coefficient correlation of those five aspects in order, the arrangements from the strongest to the weakest are: (1) Recognition for Digital Learning, (2) Learning Involvement, (3) Learning Challenge, (4) Self-Efficacy and (5) Learning Curiosity. These results show that using web-based resources in EFL learning makes the students recognize their digital learning and be aware to the need of its development as they get involved in the materials given by the teachers. In addition, when the students find that the materials are challenging for them, they become aware with the information given from the materials. Therefore, most students agree that they still read web based resources even though there were some difficulties faced by the students. This challenging aspect can contribute to the students' attitude to appropriately use digital tools to facilitate their learning development. However, students' self efficacy and curiosity slightly correlate to their digital literacy. We assume that because the students are still young and they are not really familiar the use of ICT in completing their learning task. Therefore, in enhancing their digital literacy, teachers' role is very important to encourage them to be able to navigate the net effectively and realize with the use of ICT as their learning media.

\section{Limitations}

While we found some positive impacts in this study, it would not be fair to say that there were no negative circumstances since e lack of participant $(\mathrm{n}=20)$, period of time (8 meetings), and teachers' guidance during virtual learning. For further research studies, those limitations need more attention by other researchers.

\section{Conclusion}

The research results show that students are motivated by the use of web-based resources in EFL learning. In other words, it is effective to provide the students more appropriate and authentic materials taken from web based resources to suit the students' learning comprehension and interest. Furthermore, as the impact of the digital technology advancement, learners should be familiar with other resources for their learning for instance digital resources. Therefore, it is very important to develop students' literacy skill in order to help them to be better in the future. Using web based resources can be as one of alternatives that the teachers can do in helping their students to be motivated in developing their digital literacy learning. In addition, five aspects (self efficacy, learning challenge, learning curiosity, learning involvement and recognition to digital learning) The students have willingness to develop their English better learning and enhance their digital literacy with the use of web based resources. 


\section{Reference}

Arnone, M. P., Small, R. V., Chauncey, S. A., McKenna, H. P. (2011). Curiosity, interest and engagement in technologypervasive learning environments: a new research agenda. Education Tech Research Dev, 59, 181-198.

Blanchard, J., \& Moore, T., (2010). The digital world of young children: Impact on emergent literacy. Phoenix, AZ: Pearson Foundation of Arizona State University.

Dogoriti, E. (2010). Perceptions and attitudes towards web-based ELT among English teachers in Greece. International conference ICT for language learning, $3 \mathrm{Edn}$.

Eristi, S.D.,Kurt. A.A.,\& Dindar, M. (2012). Teachers' views about effective use of technology in classrooms. Turkish online journal of qualitative inquiry, 3(2), 30-41.

Eshet-Alkalai, Y., \& Soffer, O. (2012). Guest Editorial - Navigating in the Digital Era: Digital Literacy: Socio-Cultural and Educational Aspects. Educational Technology \& Society, 15 (2), 1-1.

Giffard, A. (2011). Going digital: Digital reading and industrial reading. In K. Grandin (Ed.), Nobel Symposium 147 going digital evolutionary and revolutionary aspects of digitization (pp. 96-105). Stockholm: The Nobel Foundation.

Hartoyo (2010). Individual Differences in Computer-Assisted Language Learning. Semarang: Pelita Insani Semarang.

Jun, F. U., Pow, J. (2011). Fostering digital literacy through web-based learning-A case study. Journal of Information Technology Education: Innovations in Practice, 10, 58-71.

Kung, S.C. \& Chuo, I. (2002). Students' perceptions of English learning through ESL/EFL websites, TESL-EJ, 6(1).

Lombardi, M. M. (2007). Authentic learning for the $21^{\text {st }}$ century: An overview. Retrieved from http://net.educause.edu/ir/library/pdf/eli3009.pdf

Martin, A. (2008). Digital literacy and the "digital society". In M. K. Colin Lankshear (Ed.), Digital literacies - Concepts, policies and practice. New York, NY: Peter Lang Publishing.

McPherson, K. (2005). Reading the internet. Teacher librarian, 32 (5).

Rajanam,S.(2012). Effective use of web-based resources for enhancing ESL learning environment. Greener journal of educational research, 1 (1), 15- 18.

Salehi, H.\& Salehi, Z. (2012). Integration of ICT in language teaching: Challenges $\quad$ and barriers. IPEDR, 27 (pp.215219). IACSIT Press, Singapore.

Undang-Undang Republik Indonesia. (2005). Nomor 14 Tentang Guru dan Dosen. Retrieved from http://wrks.itb.ac.id/app/images/files_produk_hukum/uu_14_2005.pdf

Tomlinson, B. (2003). Developing materials for language teaching. New York, NY: Cromwell Press.

Vaughan, N. (2010). Student engagement and web 2.0: What's the connection? Education Canada, 50(2), 52-55.

Wigfield, A. \& Guthrie, J.T. (1997). Relations of children's motivation for reading to the amount and breadth of their reading. Journal of Educational Psychology, 89, 420-432. 